\title{
Järjestöjen vaikuttamistaktiikat internet-aikana: latentti luokka-analyysi
}

Mika Vehka \& Juho Vesa

\begin{abstract}
Associations' tactics of influence in the age of the internet: a latent class analysis

This article examines the use of different influence tactics, including both traditional (e.g., committee membership) and new internetbased tactics (e.g. social media) by interest groups (associations) in Finland. With interest group theory as our theoretical framework, we use data collected in an online survey to explore how different tactics of influence are conjointly utilised. First, a latent class analysis shows that some organizations use almost all tactics more actively than others, including internetbased tactics. Second, we study how a group's resources and type affect which 'influencer type' (active or more or less passive) they belong to. There seems to be no bias related to group type: for example business groups are not more often the most active ones compared to public citizen groups when resources are controlled.
\end{abstract}

Keywords: Interest groups, influence tactics

\section{JOHDANTO}

Etu- ja kansalaisjärjestöt ovat keskeisiä intressiryhmiä (interest groups), joiden välityksellä kansalaiset (Dur \& De Birvre 2007a, 1), tai esimerkiksi yritykset pyrkivät välittämään näkemyksiään yhteiskunnallisille päätöksentekijöille. Käytämme tässä artikkelissa näistä järjestöistä yleisnimitystä vaikuttajajärjestöt tai yleisemmin termiä intressiryhmät. Näillä ryhmillä on paljon vaikutusvaltaa politiikan teossa (esim. Baumgartner \& Leech 2001). Niillä on tärkeä merkitys myös demokratian toteutumisen kannalta, koska ne voivat tuoda päätöksentekoon tietoa esimerkiksi kansalaisten preferensseistä $(\mathrm{mm}$. Godwin ym. 2013, 26). Siksi tärkeäksi kysymyk- seksi on kirjallisuudessa noussut, saavatko esimerkiksi erilaisia tahoja edustavat organisaatiot tai eri tasoisesti resursoidut organisaatiot yhtä lailla äänensä kuuluviin poliittisissa prosesseissa, vai onko niiden vaikuttamisessa jonkinlaista systemaattista vinoumaa (bias) (esim. Godwin ym. 2013; Binderkrantz ym. 2015; Binderkrantz ym. 2017). Mukana olon tasavertaisuus on tärkeää, sillä se on myös vaikutusvallan yksi ehdoton edellytys (Bouwen 2002).

Moni tutkimus on osoittanut, että järjestöjen ja muiden intressiryhmien vaikuttaminen on kaukana "pluralistisesta" ideaalista eli siitä, että esimerkiksi erityyppisiä tahoja (esim. työntekijät, yritykset, potilaat, luonnonsuojelijat) edustavien organisaatioiden vaikutusmahdollisuudet olisivat tasavertaiset (Binderkrantz ym. 2015; Helander 1979). Kriittisempien teorioiden, vaihtosuhdeteorian ja neo-pluralistisen tutkimusperinteen mukaan erityisesti kaksi tekijää aiheuttaa epätasa-arvoa intressiryhmien välille: niiden edustamien tahojen ja ajamien tavoitteiden tyyppi ja toisaalta organisaatioiden eriävät (taloudelliset) resurssit (mm. Godwin ym. 2013).

Intressiryhmät jaotellaan usein "yleis-" ja "erityisintressiryhmiin", joista ensimmäisellä viitataan organisaatioihin, joiden jäsenet tai eturyhmät eivät ole tarkkaan rajattuja, toisin kuin jälkimmäisillä. Aiemman tutkimuksen mukaan varsinkin taloudellisia intressejä edustavat erityisintressiryhmät kuten elinkeinoelämän järjestöt ja ammattiliitot pääsevät paremmin mukaan päätösten valmisteluun ja toimeenpanoon kuin esimerkiksi kansalaisjärjestöt (Vesa ym. 2018; Binderkrantz ym. 2015). Kuvaus sopii erityisen hyvin Suomen kaltaisiin korporatistisiin järjestelmiin, joissa tietyillä etuoikeutetuilla järjestöillä on vahva, institutionalisoitunut asema päätöksentekoa valmistelevissa ja toimeenpanevissa elimissä (esim. Öberg 2002).

Lisäksi on tärkeä tarkastella myös taloudellisten resurssien merkitystä, sillä se on toinen 
merkittävä tekijä, joka aiheuttaa eroja intressiryhmien välille (mm. Godwin ym. 2013). Resurssien aiheuttamat erot järjestöjen vaikuttamismahdollisuuksissa on nähty yhteiskunnallisena ongelmana, sillä resurssit eivät jakaudu järjestökentässä esimerkiksi samassa suhteessa kuin järjestöillä on potentiaalisia jäseniä (esim. Olson, 1965; Schattschneider, 1960).

Suomessa korporatismin kultakautta oli 1970luku, jolloin työmarkkinajärjestöjen asema vahvistui keskitetyn tulopolitiikan myötä, ja ne osallistuivat lainvalmisteluun tiiviisti komiteoiden kautta (esim. Helander 1979). Tämä komitealaitos purettiin pikkuhiljaa 2000-luvulle mennessä (Temmes 2001; Rainio-Niemi 2010). Tutkimukset kuitenkin osoittavat, että näistä muutoksista huolimatta järjestöillä on edelleen oma "etuoikeutettu" eliittinsä (Vesa ym. 2018). Siihen kuuluu muun muassa elinkeinoelämän järjestöjä, ammattiliittoja ja julkisia instituutioita edustavia järjestöjä, jotka ovat kytkeytyneet tiiviisti poliittisten päätösten valmisteluun ja toimeenpanoon esimerkiksi työryhmien ja epävirallisen vuorovaikutuksen kautta. Näiden etujärjestöjen lisäksi nykyään on tarpeellista tarkastella myös erilaisia kansalaisjärjestöjä, sillä merkittävä osa maassamme tapahtuvasta kansalaistoiminnasta organisoidaan niiden kautta (mm. Oikeusministeriö 2010, 72). Kansalaisjärjestöjen nousu merkittäviksi toimijoiksi politiikkaverkostoissa on myös yleismaailmallisesti nähty vahvana kehitystrendinä (Godwin ym. 2013, 36). Tiedämme, että Suomessa on monella tavalla hyvät olosuhteet "järjestödemokratialle", kuten sangen korkea kansalaisten järjestöosallistumisaste, ja Suomea onkin kaiken kaikkiaan kuvattu erilaisten yhdistysten luvatuksi maaksi, mutta se, saavatko kaikki järjestöt tasavertaisesti äänensä kuuluviin, on edelleen kiistanalainen ja ajankohtainen kysymys.

Demokratian näkökulmasta olisi toivottavaa, että niillä järjestöillä, jotka eivät kuulu em. etuoikeutettuun eliittiin, olisi kuitenkin vaihtoehtoisia mahdollisuuksia saada äänensä kuuluviin. Erityisesti internet onkin tehnyt mahdolliseksi uusia vaikuttamistaktiikoita. Erilaiset järjestöt käyttävätkin sosiaalista mediaa aktiivisesti vaikuttaakseen julkiseen keskusteluun (Chalmers \& Shotton 2015) ja on esitetty, että sosiaalinen media saattaisi vahvistaa heikommassa asemassa olevien ryhmien asemaa (ks. esim. Van Der
Graaf ym. 2016). Samanlaisia toiveita on liitetty verkkokuulemiseen eli erilaisten internet-pohjaisten työkalujen kuten keskustelufoorumien tai verkkokyselyjen hyödyntämiseen poliittisten päätösten valmistelussa (Oikeusministeriö 2017, 37; ks. myös Wright 2016). Suomen demokratiapoliittisen toimintaohjelman mukaan internetpohjaisten kuulemismuotojen avulla "sidosryhmien ja kansalaisten kuuleminen lainvalmistelussa on muuttunut aiempaa monimuotoisemmaksi" (Oikeusministeriö 2017, 37). Ohjelman mukaan verkkokuuleminen voi "parantaa erityisesti joidenkin heikommin resursoitujen ja valmisteluun muutoin huonommin mukaan pääsevien järjestöjen mahdollisuuksia osallistua valmisteluun" (Oikeusministeriö 2017, 38). Tutkittua tietoa tästä on kuitenkin varsinkin Suomesta aivan liian vähän, vaikkakin joitain verkko-osallistumiseen liittyviä tutkimuksia on mm. viranomaisten suhtautumisesta kansalaisosallistumiseen verkon välityksellä (esim. Matikainen ym. 2008; Nelimarkka 2011). Uudet vaikuttamisareenat ovat ainakin periaatteessa kaikille avoimia, helppokäyttöisiä ja halpoja (vrt. Chalmers \& Shotton 2015, 3), mutta on kiistanalaista, vahvistavatko ne virallisen päätöksenteon ulkopuolelle jääneiden vai entisestään sisäpiiriläisten asemaa. Onkin korostettu, että myös verkkovaikuttaminen vaatii edelleen samoja asioita kuin perinteinen vaikuttaminen, kuten esimerkiksi taloudellisia resursseja (mt.).

Tässä tutkimuksessa tarkastellaan suomalaisten etu- ja kansalaisjärjestöjen vaikuttamisessa mahdollisesti olevia eroja, joita mm. järjestöjen tyyppi ja resurssit aiheuttavat. Tästä aiheesta ei juuri ole maassamme ajankohtaista tutkimusta (ks. kuitenkin mm. Saari 2012, Vesa ym. 2018). Olemme rajanneet tutkimuksen vaikuttajajärjestöihin, sillä ne ovat Pohjoismaissa keskeisiä intressiryhmiä ja esimerkiksi yritysten vaikuttaminen tapahtuu vahvasti myös niiden kautta.

Tutkimus edistää olemassa olevaa tutkimusta mm. siten, että siinä tarkastellaan yhtä aikaa myös uusia internetpohjaisia vaikuttamistaktiikoita vanhempien lisäksi (ks. kuitenkin Scaramuzzino \& Scaramuzzino 2017) ja se pyrkii tuottamaan lisää tietoa mm. siitä, mikä on uusien verkkofoorumeiden mahdollinen rooli muuten heikompien järjestöjen voimaannuttajana. Lisäksi, siinä missä aiempi tutkimus on usein keskittynyt vaikuttajajärjestöjen kokonaistason 
strategioihin, kuten vaikkapa "parlamentti-strategiaan" tai "hallinto-strategiaan" (esim. Binderkrantz 2005; Eising 2007, 341), me teemme analyysin yksittäisten vaikuttamistaktiikoiden tasolla, ja täten saadaan tietoa erilaisten yksittäisten vaikuttamisfoorumeiden demokratisoivasta potentiaalista. Ennen kuin alamme tarkastella mahdollisia eroja järjestöjen vaikuttamisessa Suomessa selvitämme minkälaisia "vaikuttajatyyppejä" maamme vaikuttajajärjestöjen joukossa nykyään on. Vaikuttajatyypillä tarkoitamme sitä, miten järjestöt yhdistelevät eri taktiikoita eri aktiivisuustasolla. Aineistona on valtakunnallisille etu- ja kansalaisjärjestöille vuodenvaihteessa 2015-2016 tehty laaja KAMU-hankkeessa kerätty kyselyaineisto (ks. Vesa \& Kantola 2016). Aineisto sisältää vastauksia erityyppisiltä yhdistyksiltä (esim. ammattiliitot, elinkeinoelämän järjestöt, kansalaisjärjestöt), jotka pyrkivät vaikuttamaan poliittisesti (katso Aineisto ja menetelmät -luku). Ryhmittelemme latentin luokkaanalyysin avulla kyselyyn vastanneet järjestöt sen perusteella, miten ne käyttävät lukuisia erilaisia vaikuttamistaktiikoita. Esitämme kirjallisuuteen perustuen hypoteesin, että toiset järjestöt ovat lähes jokaisella vaikuttamisareenalla aktiivisempia kuin toiset ja että uudet verkkopohjaiset taktiikat eivät oleellisesti muuta tilannetta.

Analyysin toisessa vaiheessa tarkastelemme regressioanalyysin avulla, miten muun muassa järjestöjen resurssit ja järjestöjen intressien tyyppi (esim. onko kyseessä elinkeinoelämän järjestö vai kansalaisjärjestö) vaikuttavat siihen, mihin vaikuttajatyyppiin järjestöt kuuluvat. Vaikuttajatyyppi on siten tutkimuksemme selitettävä muuttuja, ja järjestöjen taustatekijät selittäviä muuttujia.

\section{TEOREETTINEN VIITEKEHYS JA HYPOTEESIT}

Jotta voimme selvittää suomalaisten järjestöjen vaikuttamisen mahdollisia vinoumia, tarvitsemme kokonaiskuvan siitä, miten järjestöt käyttävät eri vaikuttamistaktiikoita eli millaisia "vaikuttajatyyppejä" järjestöjen joukossa on. Väitämme, että eri vaikuttamisfoorumeiden kohdalla eräs tärkeimmistä kysymyksistä on, aktivoivatko ne "uusia" toimijoita vai käyttäväkö niitä eniten ensisijaisesti ne, jotka ovat myös muualla aktiivisia (Oser ym. 2013). Tämä liittyy kysymykseen järjestöjen erikoistumisesta erilaisten vaikuttamis- taktiikoiden käyttöön, joka on saanut runsaasti huomiota kansainvälisessä kirjallisuudessa (esim. Dür \& Mateo 2013; Beyers 2004; Eising 2007; Binderkrantz 2005, 2008).

Kirjallisuudessa korostetaan usein, että eri tyyppiset intressiryhmät pyrkivät erikoistumaan erilaisiin vaikuttamiskeinoihin (Dür \& Mateo 2013). Organisaatioiden on sanottu painottavan toiminnassaan joko niin kutsuttuja "sisäpiiristrategioita" tai vaihtoehtoisesti" julkisia vaikuttamisstrategioita". Ensimmäisillä viitataan julkisuudelta pääosin piilossa tapahtuvaan toimintaan, esimerkiksi komiteoissa toimimiseen, jossa tietoa siirretään suoraan intressiryhmiltä julkisen sektorin toimijoille. Jälkimmäisillä taas tarkoitetaan toimintatapoja, joilla pyritään vaikuttamaan laajempiin yleisöihin esimerkiksi median välityksellä. (Beyers 2004, 212-214; Eising 2007, 340.) Usein on havaittu, että erityisesti "yleisintressiryhmät", eli yleisiä tavoitteita kuten ihmisoikeuksia tai ympäristön suojelua edistävät organisaatiot keskittyvät enemmän julkisiin vaikuttamisstrategioihin, koska julkisuus on tärkeää niille myös jäsenten hankkimisen kannalta (Della Porta \& Diani 1999, 168-169; Dür ja Mateo 2012; Binderkrantz 2008). Sen sijaan erityisesti elinkeinoelämän järjestöjen, tai muiden "erityisintressiryhmien", jotka ajavat rajatumpien toimijaryhmien asemaa, sanotaan panostavan enemmän sisäpiirivaikuttamiseen.

On kuitenkin myös tutkimusta, jonka mukaan vaikuttajajärjestöt ja muut intressiryhmät eivät erikoistukaan erilaisiin vaikuttamiskeinoihin (esim. Baumgartner \& Leech 1998; Beyers 2004, 215; Binderkrantz 2005). Esimerkiksi Beyersin (2004) mukaan ryhmien tyyppi ei selitä eri vaikuttamiskeinojen käyttöä; erityyppiset organisaatiot ainakin pyrkivät vaikuttamaan sekä sisäpiirissä että julkisuudessa. Tätä on selitetty epävarmuuden vähentämisellä: yksittäisten taktiikoiden tehokkuutta on vaikea tietää, ja tästä syystä toimijat käyttävät usein useita taktiikoita varmistaakseen vaikuttamisen onnistumisen. (Ma., 215.) Myöskään Binderkrantzin (2005) mukaan suorat ja epäsuorat vaikuttamistavat eivät ole toistensa poissulkevia vaan suuri osa intressiorganisaatioista hyödyntää hyvin erilaisia vaikuttamismuotoja (loppuviite 1 ).

Yllä mainittu Binderkrantzin (2005) havainto on merkittävä Suomen tilannetta ajatellen, sillä se on tehty Tanskassa, jota on Suomen tavoin 
pidetty korporatistisena maana (esim. Lijphart 2012; Vesa ym. 2018), tosin tutkimuksessa, jossa ei vielä tutkittu uusia internetpohjaisia vaikuttamistaktiikoita. Artikkelissamme väitämme, että korporatismin perintö näkyy nykypäivänäkin siinä, miten etu- ja kansalaisjärjestöt käyttävät myös näitä vaikuttamistaktiikoita.

Esitämme, että keskeisiä mekanismeja ilmiön takana saattaisi olla esimerkiksi virallisissa rakenteissa vahvoissa asemassa olevilla organisaatioilla oleva tieto erilaisista uusista vaikuttamiskeinoista (esimerkiksi verkkokonsultoinneista) sekä muun muassa asiantuntemus tehokkaasta vaikuttamisesta (esim. sosiaalisen median tapauksessa), joka rohkaisee vaikuttamaan. Järjestöt, joilla on vahva asema virallisilla päätöksenteon areenoilla, saavat todennäköisesti kontaktiensa kautta helpommin ja nopeammin tietoa muistakin vaikuttamiskeinoista kuten verkkokuulemisista. Niille muodostuu myös tiiviit yhteydet virkamiehiin ja päättäjiin, joita ne voivat hyödyntää verkkovaikuttamisessa esimerkiksi sosiaalisessa mediassa.

\section{H1: Toiset järjestöt käyttävät kaikkia (uusiakin) vaikuttamistaktiikoita aktiivisemmin kuin toiset.}

Mikä sitten selittää toisten organisaatioiden suurempaa aktiivisuuden tasoa? Ensinnäkin moni tutkimus on osoittanut, että mitä enemmän resursseja (esim. työntekijöitä) järjestöillä on, sitä aktiivisemmin ne käyttävät eri vaikuttamistaktiikoita, mukaan lukien sosiaalisen median kautta vaikuttamista (esim. Binderkrantz 2005; Dür \& Mateo 2013; Scaramuzzino \& Scaramuzzino 2017; Van Der Graaf ym. 2016; ks. kuitenkin Chalmers \& Shotton 2015). Mekanismeista ilmiön takana katso esim. Beyers ja Braun (2014, 94). Resurssit selittävät myös mukaan pääsyä päätösten valmisteluun ja toimeenpanoon, ja Suomessa resurssien vaikutus näyttäisi aiemman tutkimuksen mukaan olevan erityisen voimakas (Binderkrantz ym. 2015; Vesa ym. 2018). Yleisesti käytetty mittari resursseille on poliittiseen vaikuttamiseen osallistuvien työntekijöiden määrä (ks. esim. Binderkrantz 2005; Chalmers \& Shotton, 2015). Esitämme että:

H2: Resurssirikkaat järjestöt kuuluvat useammin aktiivisiin vaikuttajiin kuin resurssiköyhemmät.
Aiemman tutkimuksen mukaan toinen intressiryhmien asemaan vahvasti vaikuttava tekijä on niiden tyyppi eli se, millaisia jäseniä ja tavoitteita järjestöillä on (Godwin ym. 2013) (Taulukko 2). Korporatistisissa maissa nk. erityisintressiryhmät, kuten elinkeinoelämän järjestöt, ammattiliitot ja julkisia instituutioita (kuten esimerkiksi kuntia) edustavat järjestöt (tai ainakin osa niistä) on perinteisesti kytketty tiiviisti mukaan päätösten valmisteluun ja toimeenpanoon (esim. Binderkrantz ym. 2015), vahvemmin kuin esimerkiksi yleisempiä tavoitteita ajavat julkiset kansalaisjärjestöt (katso edellinen luku). Edellä mainittujen organisaatioiden vahvan aseman on nähty johtuvan mm. siitä, että niin kutsuttu kollektiivisen toiminnan ongelma on niillä pienempi (Olson 1965) eli että niiden on esimerkiksi helpompi saada jäsenistönsä mukaan vaikuttamistyöhön.

H3: Erityisintressiryhmät (elinkeinoelämän järjestöt, ammattiliitot ja institutionaaliset järjestöt) kuuluvat useammin aktiivisiin vaikuttajiin kuin yleisintressiryhmät (julkiset kansalaisjärjestöt).

\section{AINEISTO JA MENETELMÄT}

\section{Kyselyaineisto}

Aineistona käytämme KAMU-hankkeessa (loppuviite 2) (ks. Vesa \& Kantola 2016) vuodenvaihteessa 2015-2016 tehtyä kyselyä. Sen kohderyhmänä olivat kaikki suomalaiset valtakunnalliset etu- ja kansalaisjärjestöt, jotka pyrkivät tavalla tai toisella vaikuttamaan yhteiskunnallisesti. Järjestöillä tarkoitamme tässä julkishallinnon ulkopuolisia toimijoita, jotka ovat ainakin jollain tasolla pysyviä organisaatioita. Poliittisella vaikuttamisella viittaamme muuhun toimintaan kuin ehdokkaiden asettamiseen vaaleissa. Pääosin kyse on rekisteröidyistä yhdistyksistä.

Kyselyyn osallistuvat järjestöt kerättiin mm. käymällä vuoden ajalta läpi eduskunnan valiokuntien kuulemiset, esimerkiksi lakihankkeista ministeriöille annetut lausunnot, järjestöjen esiintymiset mediassa (Aamulehdessä ja Helsingin Sanomissa) sekä valtionhallinnon lainvalmisteluelinten jäsenyydet (loppuviite 3). Lisäksi järjestöjä etsittiin verkon avulla esimerkiksi kattojärjestöjen jäsenlistoista ja systemaattisesti 
erilaisten hakusanojen avulla (esimerkiksi Tilastokeskuksen toimialaluokitus). Kysely lähetettiin marraskuussa 2015 sähköpostitse niille 3271 järjestölle, joiden sähköpostiosoite oli verkossa saatavilla. Kyselyyn pyydettiin vastauksia henkilöiltä, jotka tuntevat hyvin järjestön yhteiskunnallista vaikuttamistoimintaa, mutta kysymykset koskivat järjestön toimintaa organisaationa, eivät vastaajan toimintaa yksilönä. Tutkimusyksikkö on siis organisaatio, ei siellä toimivat henkilöt. Vastauksia saatiin 1794. Aineistosta on suodatettu pois ne järjestöt, jotka ilmoittivat, että ne eivät pyri vaikuttamaan poliittisesti tai että ne ovat paikallisia. (Vesa \& Kantola 2016.) Jotta tulokset olisivat yleistettävissä laa- jasti suomalaisiin valtakunnallisiin vaikuttajajärjestöihin, tutkimme siis kaikkia järjestöjä, jotka ilmoittivat pyrkivänsä vaikuttamaan poliittisesti.

Kyselyssä kysyttiin mm. sitä kuinka usein viimeisen vuoden sisällä järjestö on käyttänyt 27 :ää eri toimintatapaa saadakseen poliittista vaikutusvaltaa (taulukko 1). Vaihtoehdot olivat "erittäin usein", "melko usein", "silloin tällöin" tai "ei kertaakaan". (Vesa \& Kantola 2016, 79-93.) Näiden kysymysten avulla etsitään tutkimuksessamme erilaisia vaikuttajatyyppejä. Kysymykset ovat samanlaisia kuin Binderkrantzin (2005) käyttämät, lukuun ottamatta sitä, että edellä mainitussa tutkimuksessa ei ollut tutkittu verkkovaikuttamista.

Taulukko 1. Intressiryhmien mahdolliset vaikuttamistaktiikat tässä tutkimuksessa.

- Kansalaistottelemattomuus ja laiton toiminta

- Lailliset mielenosoitukset, julkiset tapahtumat, jne.

- Kannustamme jäseniämme ja muita ihmisiä kirjoittamaan yleisönosastokirjoituksia

- Kannustamme jäseniämme ja muita ihmisiä ottamaan yhteyttä päätöksentekijöihin

- Nimien kerääminen adresseihin

- Keskustelutilaisuuksien ja konferenssien järjestäminen

- Mainostaminen esimerkiksi sanomalehdissä

- Yleisönosastokirjoitusten kirjoittaminen

- Lehdistötiedotteiden julkaiseminen ja lehdistötilaisuuksien järjestäminen

- Yhteydenotot toimittajiin

- Analyysien ja tutkimusten julkaiseminen

- Yhteydenotot eduskunnan valiokuntiin

- Yhteydenotot poliittisten puolueiden johtaviin poliitikkoihin

- Yhteydenotot muihin kansanedustajiin

- Yhteydenotot puolueorganisaatioihin

- Yhteydenotot ministereihin

- Yhteydenotot valtion virkamiehiin

- Lausuntojen antaminen

- Neuvottelukuntien, lautakuntien, toimikuntien tai julkisten valmistelutyöryhmien jäsenyyden hyödyntäminen

- Yhteydenotot EU-instituutioihin

- Oikeusprosessin käynnistäminen (esim. kanne)

- Blogikirjoitusten julkaiseminen

- Muiden kirjoitusten tai kuvien julkaiseminen sosiaalisessa mediassa (esim. Facebookissa tai Twitterissä)

- Videoiden julkaiseminen sosiaalisessa mediassa

- Osallistuminen verkkokeskusteluihin tai verkkokyselyihin Otakantaa.fi-palvelussa

- Osallistuminen muihin julkisen hallinnon järjestämiin verkkokeskusteluihin tai verkkokyselyihin

- Kannustamme jäseniämme osallistumaan julkisen hallinnon järjestämiin verkkokeskusteluihin tai verkkokyselyihin 
Aineistossa on myös taustatietoa järjestöistä, jonka avulla selitämme eri vaikuttajatyyppeihin kuulumista. Nämä taustatiedot koskevat muun muassa järjestöjen taloudellisia resursseja, järjestöjen tyyppiä ja järjestöjen vaikuttamistoiminnan laajuutta sekä pyrkimystä vaikuttaa poliittisesti. Järjestöjen resurssien mittarina käytetään niiden itse ilmoittamaa poliittiseen vaikuttamiseen osallistuvien työntekijöiden määrää. Toinen keskeinen selittävä muuttuja on järjestön tyyppi, joka luokiteltiin INTERARENA-projektin luo- kittelurungon perusteella (loppuviite 4). Kyselyyn vastanneet järjestöt luokiteltiin kahdeksaan luokkaan (taulukko 2): ammattiliitot, elinkeinoelämän järjestöt, institutionaaliset järjestöt, professionaaliset järjestöt, identiteettijärjestöt, harrastejärjestöt, uskonnolliset järjestöt ja julkiset kansalaisjärjestöt, joista viimeisimmät 4 luokkaa ovat erilaisia kansalaisjärjestöjä. Taulukossa 2 on kuvattu tarkemmin kunkin kategorian määrittely ja esitetty esimerkkejä Suomesta.

\begin{tabular}{|c|c|c|}
\hline Kategoria & Määrittely & Esimerkkejä Suomesta \\
\hline Ammattiliitot & $\begin{array}{l}\text { Työntekijäjärjestöt, jotka neuvottelevat } \\
\text { työehdoista tai muuten pyrkivät parantamaan } \\
\text { työolosuhteita tai työehtoja }\end{array}$ & Lääkäriliitto \\
\hline Elinkeinoelämän järjestöt & Järjestöt, joissa on ensisijaisesti yrityksiä jäseninä & Hyvinvointiala HALI \\
\hline Institutionaaliset järjestöt & $\begin{array}{l}\text { Julkisten viranomaisten tai instituutioiden } \\
\text { järjestöt }\end{array}$ & Kuntaliitto \\
\hline Professionaaliset järjestöt & $\begin{array}{l}\text { Ammattikuntien järjestöt, jotka eivät neuvottele } \\
\text { työehdoista }\end{array}$ & Lääkäriseura Duodecim \\
\hline Identiteettijärjestöt & $\begin{array}{l}\text { Jäsenillä on työhön liittymätön erityinen intressi } \\
\text { ryhmän tavoitteissa }\end{array}$ & Eläkeliitto \\
\hline Harrastejärjestöt & $\begin{array}{l}\text { Järjestö, jonka jäsenillä on yhteinen urheiluun tai } \\
\text { vapaa-aikaan liittyvä intressi }\end{array}$ & Suomen Urheiluliitto SUL \\
\hline Uskonnolliset järjestöt: & Uskonnon jakavien jäsenten järjestö & Sininauhaliitto \\
\hline Julkiset kansalaisjärjestöt: & $\begin{array}{l}\text { Järjestöt, joiden jäsenillä ei ole erityistä } \\
\text { henkilökohtaista intressiä ryhmän tavoitteissa }\end{array}$ & Ihmisoikeusliitto \\
\hline
\end{tabular}

Lisäksi kontrolloimme kaksi tekijää, joiden oletamme vaikuttavan taktiikoiden käyttöön. Vaikuttamisen "laajuutta" mittaava muuttuja kuvaa sitä, miten laajasti järjestö on aktiivinen 19 eri politiikkasektorilla. Vastauksista muodostettiin summamuuttuja laskemalla ne yhteen seuraavasti: erittäin (aktiivinen) $=3$; jokseenkin (aktiivinen $)=2$; vähän $($ aktiivinen $)=1$; ei ollenkaan (aktiivinen) tai puuttuva tieto $=0$ (Binderkrantz 2005). Suuret luvut kuvastavat, että järjestö on laajasti aktiivinen ja pienemmät viittaavat sup- peampaan aktiivisuuteen eri sektoreilla. Toinen kontrollimuuttuja mittaa järjestöjen pyrkimystä vaikuttaa poliittisesti. Kyseessä on keskiarvo järjestöjen vastauksista kysymyksiin, miten paljon ne pyrkivät vaikuttamaan (asteikolla paljon; jonkin verran; vähän; ei ollenkaan [käännetty]): kansalaisten mielipiteisiin; median käsittelemiin aiheisiin; politiikan asialistaan; lainsäädäntöön tai eduskunnan päätöksiin; hallinnollisiin määräyksiin tai ohjeisiin ja julkisen hallinnon tekemiin päätöksiin. (Vrt. Binderkrantz 2005.) 


\section{Analyysimenetelmät}

Voidaksemme testata hypoteesia 1 tarvitsemme ryhmittelymenetelmän, joka etsii erilaisia "vaikuttajatyyppejä" järjestöjen eri taktiikoita koskevien vastausten perusteella. Päädyimme käyttämään ryhmittelymenetelmänä latenttia luokka-analyysiä (LCA; loppuviite 5), joka soveltuu hyvin luokittelu- tai järjestysasteikollisten muuttujien tapauksessa silloin, kun halutaan etsiä erilaisia "käyttäytymistyyppejä" (Hagenaars \& Halman 1989). Menetelmä muistuttaa yleisemmin käytettyä faktorianalyysiä siinä, että se tunnistaa piilossa olevia rakenteita useiden indikaattoreiden avulla. Siinä missä faktorianalyysi perustuu korrelaatioihin eri indikaattoreiden välillä, luokittelee LCA tutkimusyksiköt perustuen vastauskuvioiden yhtäläisyyteen. Tulokset kertovat eri luokkiin kuuluvien järjestöjen ehdolliset todennäköisyydet valita vaikuttamistaktiikoita koskevien kysymysten eri vastausvaihtoehdot (nämä ovat analogisia faktorianalyysin "faktorilatausten" kanssa). (Katso mm. Oser ym. 2013.) Menetelmää onkin käytetty politiikan tutkimuksessa (Hooghe ym. 2016) ja eritoten poliittisen osallistumisen tutkimuksessa, kun on selvitetty muun muassa, miten kansalaiset yhdistävät erilaisia osallistumismuotoja eri aktiivisuustasolla (esim. Oser ym. 2013). Meidän tutkimuksemme soveltaa menetelmää intressiorganisaatioiden tutkimuksessa saman tyyppisesti kuin Oser ym. (2013) käyttivät sitä tutkiessaan yksittäisiä kansalaisia ja sitä, onko verkkovaikuttaminen heillä oma osallistumisen muotonsa, jota harrastavat muut kuin muuten aktiiviset kansalaiset.

Edelleen tarkastelemme, miten järjestöjen taustatekijät, kuten niiden intressien tyyppi tai taloudelliset resurssit, vaikuttavat niiden kuulumiseen edellisen menetelmän avulla löytyneisiin luokkiin (eli vaikuttajatyyppeihin). Tämä toteutetaan latent class regression (LCR) -menetelmän (Linzer ym. 2011, 7) avulla, joka on regressioanalyysin variaatio, jonka tulosten tulkinta muistuttaa pääpiirteissään perinteisempien regressioanalyysien tulosten tulkintaa. Ajoimme analyysit R-kielen poLCA-ohjelmalla. Ohjelma antaa LCR:n osalta multinomiaaliset logit -kertoimet (mts. 13). Oleellista tässä analyysissä on meidän hypoteesiemme kannalta pääasiassa vaikutuksen suunta, eli se, ovatko kertoimet positiivisia tai negatiivisia. Esimerkiksi positiiviset kertoimet kertovat siitä, että selittävien muuttujien arvojen kasvaminen lisää järjestön todennäköisyyttä kuulua tiettyyn luokkaan.

\begin{tabular}{|lc|}
\hline $\begin{array}{l}\text { Taulukko 3. Bayesian Information Criterion (BIC) } \\
\text { arvot eri luokkien määrillä. }\end{array}$ \\
\hline 2 & BIC \\
3 & 55301.71 \\
4 & 53544.43 \\
5 & 53184.26 \\
\hline $\begin{array}{l}\text { Pienemmär } \\
\text { sopivuutta ja suuremmat huonompaa. } \\
\text { Aineisto: KAMU-hankkeen kyselyaineisto } \\
\text { (Aineisto- ja menetelmät -luku). }\end{array}$ \\
\hline
\end{tabular}

\section{Sopiva luokkien määrä}

LCA:ta käyttävän tutkijan on määritettävä, kuinka moneenluokkaan aineistojaetaan. Selvitimme sopivaa luokkien määrää aineistolähtöisesti, Bayesian Information Criterion (BIC) arvoja käyttäen, kuten menetelmää käytettäessä tyypillisesti tehdään. Pienemmät BIC-arvot kuvaavat parempaa sopivuutta ja suuremmat huonompaa. Luokkien lisäämisestä saatava "lisäarvo" väheni selvästi joka kerta, kun luokkien määrää lisätään, ennen kaikkea neljännen luokan jälkeen (Taulukko 3) joten valitsimme tämän luokkamäärän (valitettavasti ohjelmamme avulla ei voitu laskentatehollisista syistä tehdä analyysiä kovin suurilla luokkamäärillä). Varmuuden vuoksi teimme analyysin myös muilla luokkamäärillä ja havaitsimme vastaavanlaisia tuloksia kuin alla kuvatussa analyysissä.

\section{TULOKSET}

\section{Eri vaikuttajatyypit (hypoteesi 1)}

LCA jakoi aineiston perusteella intressiorganisaatiot neljään ns. piilevään luokkaan perustuen vaikuttamistaktiikoita koskevien kysymysten "vastauskuvioiden" yhtäläisyyteen. Tulkinnan helpottamiseksi raportoimme, kuinka suuri osuus järjestöistä kussakin luokassa käyttää kutakin vaikuttamistaktiikkaa vähintään melko usein 
(kuvio 1). Luokat "erittäin usein" ja "melko usein" on siis yhdistetty (LCA-analyysin jälkeen).

Tarkastelemme seuraavaksi, erottaako eri piilevien luokkien organisaatioita eri taktiikoiden painottaminen vai vain yleinen aktiivisuuden taso (hypoteesi 1). Tässä kohtaa on hyvä huomata, että menetelmälle ei ole annettu etukäteen mitään taktiikoiden käyttöä koskevien kysymysten vastauskuvioita tarkempaa perustetta, jonka mukaan se jakaa intressiorganisaatiot; esimer- kiksi aktiivisuustaso ei ole mitenkään ennalta määrätty jaotteleva tekijä.

Kuten kuviosta 1 näkyy, voidaan sanoa, että järjestöjen yleinen aktiivisuus eri taktiikoiden käytössä vaihtelee paljon. Esimerkiksi kansalaistottelemattomuutta ja laitonta toimintaa käytetään kaikissa luokissa todella harvoin, kun taas muiden kirjoitusten tai kuvien julkaiseminen sosiaalisessa mediassa on sangen aktiivisesti käytetty vaikuttamistaktiikka kaikissa luokissa.

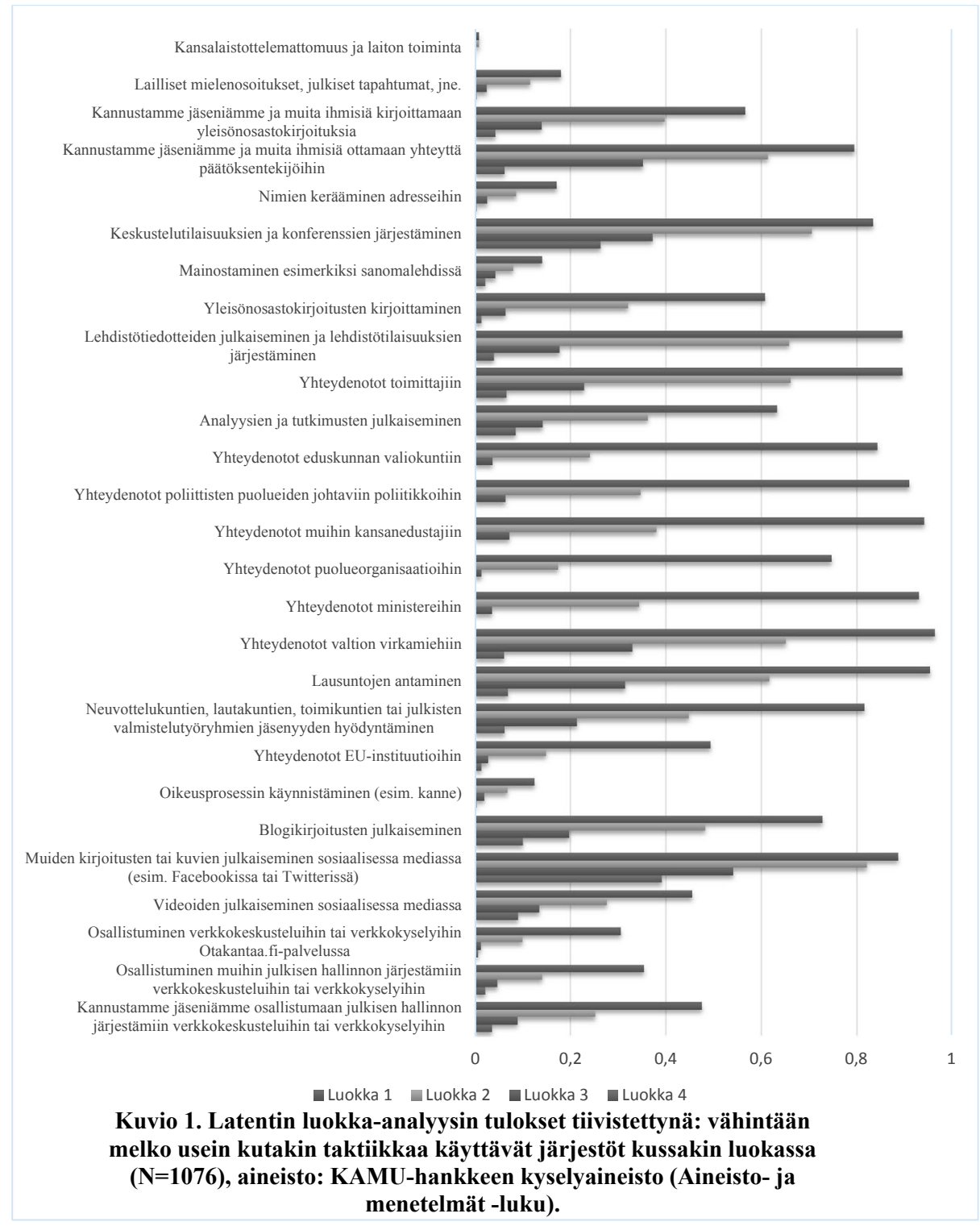


Tulosten perusteella ensimmäinen hypoteesimme saa tukea aineistosta: Ensimmäisessä luokassa käytetään kaikkia vaikuttamistaktiikoita yleisemmin vähintään melko usein kuin muissa luokissa, lukuun ottamatta kansalaistottelemattomuutta ja laitonta toimintaa. Toisessa luokassa järjestöt ovat (tätä yhtä taktiikkaa lukuun ottamatta) aina toiseksi aktiivisimpia, kolmannessa kolmanneksi aktiivisimpia ja neljännessä kaikista passiivisimpia. Järjestöjen "vastauskuviot" eroavat siis analyysin perusteella toistaan ennen kaikkea siinä, kuinka aktiivisia järjestöt yleisesti ovat.

Tämä havaittu sääntö näyttää pätevän, vaikka mukana kyselyssä on myös uusia internetpohjaisia vaikuttamiskeinoja. Verkkovaikuttaminen ei siis näytä (ainakaan Suomessa) olevan, ainakaan vielä, selvästi mikään oma, muusta vaikuttamisesta erillään oleva vaikuttamisen muotonsa intressiorganisaatioiden kohdalla. Tilanne on erilainen kuin on havaittu eräissä kansainvälisissä tutkimuksissa, joissa on selvitetty yksittäisten kansalaisten poliittista osallistumista (Oser ym. 2013). Intressiorganisaatioiden osalta uudet internetpohjaiset ja vanhat vaikuttamistaktiikat näyttävät siis olevan enemmänkin toisiaan tukevia kuin keskenään vaihtoehtoisia.

Tulosten tarkempi analyysi kuitenkin osoittaa, että tilanne on hieman monimutkaisempi. Toiset järjestöt näyttävät käyttävän toisia taktiikoita ainakin suhteellisesti enemmän kuin toisia, ja suhteelliset painotukset vaihtelevat luokittain. Tämä voi kertoa jotain esimerkiksi uusien internetpohjaisten vaikuttamisfoorumeiden demokratisoivista mahdollisuuksista. Olemme kuitenkin analyysin teon jälkeen nimenneet organisaatioiden luokat niiden jäsenten yleisemmän aktiivisuustason mukaan.

\section{Luokka 1: Vaikuttajajärjestöjen eliitti}

Ensimmäisen luokan järjestöt (10,3 \% organisaatioista) käyttävät kaikkia tutkittuja vaikuttamistaktiikoita - paitsi kansalaistottelemattomuutta ja laitonta toimintaa - useammin vähintään melko usein kuin organisaatiot muissa luokissa. Tästä syystä luokan järjestöjä voi hyvällä syyllä kutsua järjestöjen eliitiksi.

Kun katsoo, mitä taktiikoita tämän luokan jäsenet käyttävät suhteellisesti aktiivisimmin, huomaa, että ryhmien eliitin jäsenet painottavat ennen kaikkea suoria kontakteja erilaisiin toimijoihin. Viisi eniten käytettyä taktiikkaa tässä luokassa ovat yhteydenotot valtion virkamiehiin (96,4 \% käyttää vähintään melko usein), lausuntojen antaminen (95,4\%), yhteydenotot muihin kansanedustajiin (94,1\%), yhteydenotot ministereihin $(93,0)$ ja yhteydenotot poliittisten puolueiden johtaviin politikkoihin (91,0\%).

Yli 80 prosenttia näistä järjestöistä käyttää myös vähintään melko aktiivisesti taktiikoita lehdistötiedotteiden julkaiseminen ja lehdistötilaisuuksien järjestäminen, yhteydenotot toimittajiin, muiden kirjoitusten tai kuvien julkaiseminen sosiaalisessa mediassa, yhteydenotot eduskunnan valiokuntiin, keskustelutilaisuuksien ja konferenssien järjestäminen ja neuvottelukuntien, lautakuntien, toimikuntien tai julkisten valmistelutyöryhmien jäsenyyden hyödyntäminen. Nämä järjestöt ovat siis pääosin todella aktiivisia hyvin monenlaisten taktiikoiden käyttämisessä. Suorat yhteydenotot päätöksentekijöihin ja esimerkiksi mediaan liittyvät taktiikat eivät siis näytä olevan keskenään ristiriidassa (Binderkrantz 2005), niin kuin eivät suorat yhteydenotot ja sosiaaliseen mediaan liittyvät taktiikatkaan.

Harvemmin tässä luokassa käytetään sen sijaan sellaisia taktiikoita kuin lailliset mielenosoitukset, julkiset tapahtumat, jne. (18,0\%), nimien kerääminen adresseihin (17,1\%), mainostaminen esimerkiksi sanomalehdissä (14,0\%), oikeusprosessin käynnistäminen (esim. kanne) (12,5\%) ja kansalaistottelemattomuus ja laiton toiminta $(0,9 \%)$. Jäsenten mobilisointi ja jotkin julkisuutta hyödyntävät taktiikat ovat siis harvinaisempia tämän luokan järjestöissä, vaikkakin on huomattava että ne ovat myös näissä taktiikoissa useammin aktiivisia kuin järjestöt muissa luokissa.

\section{Luokka 2: Keskiaktiiviset järjestöt}

Seuraavaan luokkaan kuuluvat järjestöt (22,3 \% kaikista) käyttävät eri vaikuttamiskeinoja lähes kautta linjan toiseksi aktiivisimmin. Siksi kutsumme niitä keskiaktiivisiksi järjestöiksi.

Keskiaktiiviset järjestöt painottavat toiminnassaan suhteellisesti useammin ennen kaikkea erilaisia "ulkopuolisia" vaikuttamiskeinoja, kuten mediaan liittyviä taktiikoita. Viiden aktiivisimmin käytetyn taktiikan kohdalla ovat muiden kirjoitusten tai kuvien julkaiseminen sosiaalisessa mediassa (esim. Facebookissa tai Twitterissä) $(82,1 \%$ järjestöistä käyttää vähintään melko usein), keskustelutilaisuuksien ja konferenssien järjestäminen (70,5\%), yhteydenotoissa toimitta- 
jiin (66,1 \%), lehdistötiedotteiden julkaiseminen ja lehdistötilaisuuksien järjestäminen (65,8\%) sekä yhteydenotot valtion virkamiehiin $(65,1 \%)$. Näistä ensimmäisen taktiikan käyttö korostaa jälleen kerran sosiaalisen median merkitystä.

Harvimmin sen sijaan vaikutettiin osallistumalla verkkokeskusteluihin tai verkkokyselyihin Otakantaa.fi -palvelussa (10,0\%), keräämällä nimiä adresseihin (8,6 \%) mainostamalla esimerkiksi sanomalehdissä (8,0\%), käynnistämällä oikeusprosessi (esim. kanne) (6,8 \%) sekä kansalaistottelemattomuudella ja laittomalla toiminnalla $(0,9 \%)$.

Luokka 3: Melko passiiviset järjestöt

Tämän luokan organisaatiot (38,0 \% kaikista) ovat kauttaaltaan vähemmän aktiivisia kuin järjestöt kahdessa edellisessä luokassa, mutta useammin aktiivisia kuin luokan 4 ryhmät. Tähän luokkaan kuuluvia järjestöjä voidaan täten kutsua melko passiivisiksi.

Näiden järjestöjen kohdalla ei ole helppoa nähdä varsinaista erikoitumista tietyn tyyppisten taktiikoiden käyttöön, eli selkeää "strategiaa". Viiden useimmiten aktiivisesti käytetyn taktiikan kohdalla löytyy sellaisia kuin muiden kirjoitusten tai kuvien julkaiseminen sosiaalisessa mediassa (esim. Facebookissa tai Twitterissä) (54,1\%), keskustelutilaisuuksien ja konferenssien järjestäminen (37,3\%), jäsenten ja muiden ihmisten kannustaminen ottamaan yhteyttä päätöksentekijöihin $(35,2 \%)$, yhteydenotot valtion virkamiehiin (33,0 \%) ja lausuntojen antaminen $(31,4 \%)$. Jälleen kerran sosiaalisen media merkitys korostuu.

Vain harvat tämän luokan järjestöt käyttävät muita taktiikoita vähintään melko usein. Vähiten käytettiin sellaisia taktiikoita kuin lailliset mielenosoitukset, julkiset tapahtumat, jne. (2,5\%), oikeusprosessin käynnistäminen (esim. kanne) $(1,9 \%)$, yhteydenotot puolueorganisaatioihin $(1,4 \%)$, osallistuminen verkkokeskusteluihin tai verkkokyselyihin Otakantaa.fi-palvelussa $(1,3 \%)$ ja kansalaistottelemattomuus ja laiton toiminta $(0,2 \%)$.

\section{Luokka 4: Passiivisimmat järjestöt}

Viimeisimmän luokan vaikuttajajärjestöt $(29,4$ $\%$ kaikista ryhmistä) ovat kaikkien vaikuttamiskeinojen kohdalla vähiten aktiivisia, joten niitä voidaan kutsua passiivisimmiksi järjestöiksi.
Passiivisimmat järjestöt käyttävät ennen kaikkea erilaisia virallisen päätöksenteon ulkopuolisia vaikuttamiskeinoja, etenkin sosiaalista mediaa. Viisi aktiivisimmin käytettyä taktiikkaa ovat muiden kirjoitusten tai kuvien julkaiseminen sosiaalisessa mediassa (esim. Facebookissa tai Twitterissä) (39,1 \% käyttää vähintään melko usein), keskustelutilaisuuksien ja konferenssien järjestäminen (26,3\%), blogikirjoitusten julkaiseminen (10,0\%), videoiden julkaiseminen sosiaalisessa mediassa $(9,0 \%)$ ja analyysien ja tutkimusten julkaiseminen (8,6\%).

Yhteydenotot eduskunnan valiokuntiin, poliittisten puolueiden johtaviin politikkoihin, muihin kansanedustajiin, puolueorganisaatioihin sekä ministereihin sekä kansalaistottelemattomuus ja laitonta toiminta ovat vaikutuskeinoja, joita yksikään tämän luokan jäsenistä ei harrasta vähintään melko usein. Tämäkin korostaa sitä seikkaa, että suorat kontaktit päätöksentekijöihin ovat muutenkin aktiivisten järjestöjen vaikuttamiskeinoja. Sosiaalista mediaa käytetään tässä luokassa suhteellisen aktiivisesti, niin kuin muissakin luokissa.

\section{Yhteenveto vaikuttajatyypeistä}

Kaiken kaikkiaan hypoteesi 1 saa siis vahvaa tukea aineistosta, jos tarkastellaan vaikuttajajärjestöjen aktiivisuutta verrattuna muihin järjestöihin. Jos taas katsotaan suhteellista aktiivisuutta (verrattuna toisiin taktiikoihin), eroja eri luokkien järjestöjen välillä löytyy. Suorat vaikuttamiskeinot näyttävät olevan erityisesti kaikista aktiivisimpien järjestöjen vaikutuskeinoja. Muun muassa sosiaalinen media näyttää tarjoavan parhaiten vaikuttamismahdollisuuksia sellaisille järjestöille, jotka ovat yleisesti passiivisimpia.

Julkisen sektorin verkkopohjaiset konsultaatiofoorumit eivät varsinaisesti erotu tässä analyysissä mihinkään suuntaan. Esimerkiksi julkisen hallinnon järjestämiin verkkokeskusteluihin tai -kyselyihin Otakantaa-palvelussa tai muilla alustoilla osallistuivat vähintään melko usein pääasiassa jotkin vaikuttajajärjestöjen eliitin jäsenet (noin kolmasosa eliitin jäsenistä). Muissa luokissa näiden taktiikoiden harrastaminen oli selvästi harvinaisempaa, ja eri luokkien jäsenten aktiivisuus näissä taktiikoissa seuraili niiden yleisempää aktiivisuuden tasoa. 
Eri luokkien organisaatioiden taustatekijät (hypoteesit 2 ja 3)

Seuraavaksi tarkastellaan eri luokkien organisaatioiden taustatekijöitä LCR-menetelmän avulla (taulukko 4), ja pyritään vastaamaan kysymykseen siitä, minkälaisia mahdollisia vinoumia suomalaisten järjestöjen vaikuttamisessa on liittyen resursseihin (hypoteesi 2) ja järjestöjen tyyppiin (hypoteesi 3 ). Vertailukategoriana ovat keskiaktiiviset järjestöt. Kertoimet kuvaavat, lisäävätkö (positiiviset kertoimet) vai vähentävätkö (negatiiviset kertoimet) järjestön eri taustatekijät niiden todennäköisyyttä kuulua tiettyyn luokkaan sen sijaan, että ne kuuluisivat vertailuluokkaan eli keskiaktiivisiin järjestöihin.

\begin{tabular}{|c|c|c|c|}
\hline & $\begin{array}{l}\text { Luokka } 1 \\
\text { (ref. 2) }\end{array}$ & $\begin{array}{l}\text { Luokka } 3 \\
\text { (ref. 2) }\end{array}$ & $\begin{array}{l}\text { Luokka } 4 \\
\text { (ref.2) }\end{array}$ \\
\hline Vakio & $\begin{array}{l}-9.81 * * * \\
(2.56)\end{array}$ & $\begin{array}{l}7.87 * * * \\
(1.05)\end{array}$ & $\begin{array}{l}\mathbf{1 5 . 5 7 * * *} \\
(1.45)\end{array}$ \\
\hline Vaikuttamisen laajuus & $\begin{array}{l}0.03 \\
(0.03)\end{array}$ & $\begin{array}{l}-\mathbf{0 . 0 8 * * *} \\
(0.02)\end{array}$ & $\begin{array}{l}-0.22 * * * \\
(0.03)\end{array}$ \\
\hline Vaikuttaminen tavoitteena & $\begin{array}{l}1.93 * * \\
(0.68)\end{array}$ & $\begin{array}{l}-1.07 * * * \\
(0.28)\end{array}$ & $\begin{array}{l}-\mathbf{2} .33 * * * \\
(0.34)\end{array}$ \\
\hline Pol. henkilöstö (log.) & $\begin{array}{l}1.25 * * \\
(0.46)\end{array}$ & $\begin{array}{l}-\mathbf{2 . 7 9 * * *} \\
(0.44)\end{array}$ & $\begin{array}{l}-5.92 * * * \\
(0.91)\end{array}$ \\
\hline \multicolumn{4}{|l|}{ Intressien tyyppi (ref. julkinen) } \\
\hline - Ammattiliitto & $\begin{array}{l}-1.08 \\
(0.95)\end{array}$ & $\begin{array}{l}1.26^{*} \\
(0.57)\end{array}$ & $\begin{array}{l}0.63 \\
(0.69)\end{array}$ \\
\hline - Elinkeinoelämän järj. & $\begin{array}{l}-0.46 \\
(0.82)\end{array}$ & $\begin{array}{l}0.61 \\
(0.51)\end{array}$ & $\begin{array}{l}0.50 \\
(0.59)\end{array}$ \\
\hline - Institutionaalinen järj. & $\begin{array}{l}0.24 \\
(0.81)\end{array}$ & $\begin{array}{l}0.62 \\
(0.60)\end{array}$ & $\begin{array}{l}-0.54 \\
(0.89)\end{array}$ \\
\hline - Professionaalinen järj. & $\begin{array}{l}-0.65 \\
(1.25)\end{array}$ & $\begin{array}{l}0.97 \\
(0.59)\end{array}$ & $\begin{array}{l}\text { 1.31* } \\
(0.63)\end{array}$ \\
\hline - Identiteetti-järj. & $\begin{array}{l}-0.29 \\
(0.70)\end{array}$ & $\begin{array}{l}0.24 \\
(0.51)\end{array}$ & $\begin{array}{l}-0.66 \\
(0.64)\end{array}$ \\
\hline - Harrastejärj. & $\begin{array}{l}-0.98 \\
(1.05)\end{array}$ & $\begin{array}{l}0.66 \\
(0.56)\end{array}$ & $\begin{array}{l}-0.10 \\
(0.66)\end{array}$ \\
\hline - Uskonnollinen järj. & $\begin{array}{l}-0.57 \\
(2.64)\end{array}$ & $\begin{array}{l}0.63 \\
(0.83)\end{array}$ & $\begin{array}{l}0.58 \\
(1.06)\end{array}$ \\
\hline \multicolumn{4}{|c|}{$\begin{array}{l}\text { Kertoimien tilastollinen merkitsevyys on ilmoitettu mallissa seuraavasti: }{ }^{* * *} p<0.001,{ }^{* *} p<0.01 \\
{ }^{*} p<0.05 \text {. Kertoimien keskivirhe on suluissa kertoimen alla. Muuttujien operationalisoinnista } \\
\text { katso aineisto ja menetelmät -luku. Aineisto: KAMU-hankkeen kyselyaineisto (Aineisto- ja } \\
\text { menetelmät -luku). }\end{array}$} \\
\hline
\end{tabular}

Kun katsotaan järjestöjen eliitin taustatekijöitä, huomataan, että mitä vahvemmin järjestöillä on vaikuttaminen tavoitteena ja mitä enemmän niillä on poliittista henkilöstöä, sitä todennäköisemmin ne kuuluvat järjestöjen eliittiin (ker- toimet 1.93 ja $1.25 ; \mathrm{p}<0,01$ ) sen sijaan että ne kuuluisivat vertailukategoriaan eli toiseksi aktiivisimpiin järjestöihin. Järjestöjen eliitti näyttää siis hypoteesin 2 mukaisesti koostuvan vertailuryhmää resurssirikkaimmista järjestöistä. 
Hypoteesin 3 vastaisesti sen sijaan järjestöjen tyyppi ei näytä vaikuttavan eliittiin kuulumiseen. Esimerkiksi elinkeinoelämän järjestöt eivät näytä olevan useammin tämän luokan jäseniä kuin julkiset kansalaisjärjestöt.

Melko passiiviset järjestöt ovat sen sijaan suhteessa vertailuryhmään eli keskiaktiivisiin järjestöihin vähemmän laajasti vaikuttamaan pyrkiviä ja resurssiköyhempiä järjestöjä: Vaikuttamisen laajuus, vaikuttaminen tavoitteena sekä poliittinen henkilöstö -muuttujat ovat tilastollisesti merkitsevässä negatiivisessa yhteydessä (kertoimet $-0.08,-1.07 \mathrm{ja}-2.79 ; \mathrm{p}<0,001$ ) tähän ryhmään kuulumiseen. Lisäksi ammattiliitot näyttävät olevan hieman yllättäen useammin tämän ryhmän jäseniä verrattuna julkisiin kansalaisjärjestöihin (kerroin 1.26; $\mathrm{p}<0,05$ ). Jälleen tuloksissa korostuu se, että resurssit ovat vahvasti yhteydessä aktiivisuuteen poliittisessa vaikuttamisessa, mutta vaikuttajajärjestöjen intressien tyyppi ei niinkään.

Passiivisimmat järjestöt muistuttavat taustatekijöiltään melko passiivisia järjestöjä. Vaikuttamisen laajuus, vaikuttaminen tavoitteena ja poliittinen henkilöstö-muuttujat ovat negatiivisessa yhteydessä tähän luokkaan kuulumisen kanssa, verrattuna keskiaktiivisiin järjestöihin kuulumiseen (kertoimet $-0.22,-2.33$ ja $-5.92 ; \mathrm{p}<0,001$ ). Nämä järjestöt ovat siis myös odotetusti resurssiköyhempiä järjestöjä, joilla poliittinen vaikuttaminen ei ole niin suuri osa toimintaa. Toisaalta hypoteesin 3 vastaisesti järjestöjen intressien tyyppi ei näytä juurikaan selittävän tähän luokkaan kuulumista. Vain professionaaliset järjestöt kuuluvat hieman useammin tähän ryhmään verrattuna julkisiin kansalaisjärjestöihin (1.31; $\mathrm{p}<0,05)$. Jälleen esimerkiksi elinkeinoelämän järjestöt ja julkiset kansalaisjärjestöt näyttävät kuuluvan tähän ryhmään yhtä todennäköisesti. Kaiken kaikkiaan $\mathrm{H} 2$ saa siis tukea aineistosta, mutta $\mathrm{H} 3$ ei.

\section{YHTEENVETO JA JOHTOPÄÄTÖKSET}

Demokratian kannalta tärkeä kysymys on, miten erilaiset intressiryhmät saavat äänensä kuuluviin. Selvittääksemme tilannetta Suomessa, olemme tarkastelleet ensinnäkin, minkälaisia vaikuttajatyyppejä etu- ja kansalaisjärjestöjemme joukossa on. Tulostemme mukaan tämän päivän "jälki-korporatistisessa" Suomessa, jossa järjestöillä on paljon uusia ja vanhoja vaikuttamiskeinoja, toiset järjestöt näyttävät käyttävän lähes kaikkia vaikuttamiskeinoja aktiivisemmin kuin toiset. Löysimme neljä luokkaa, joista yhden jäsenet ovat kautta linjan vertailuryhmään verrattuna aktiivisempia ja kaksi luokkaa, joiden jäsenet ovat vertailuryhmään suhteutettuna passiivisempia.

Toisaalta, vaikka yleinen aktiivisuustaso on eniten eri luokkien järjestöjä kuvaava tekijä, on luokkien sisällä havaittavissa suhteellisia painotuseroja. Kaikista aktiivisimmat järjestöt painottavat toiminnassaan erityisesti suoria yhteyksiä erilaisiin päätöksentekijöihin; keskiaktiiviset taas vaikuttavat enemmänkin virallisen päätöksenteon ulkopuolella, esimerkiksi mediassa; kaikista passiivisimmat painottavat sen sijaan $\mathrm{mm}$. sosiaalista mediaa vaikuttamiskanavana. Tämän taktiikan suhteen järjestöt ovat jopa suhteellisen aktiivisia. Nämä painotuserot saattavat ainakin osittain johtua siitä, että vaikuttaminen poliittiseen päätöksentekoon ei ole yhtä vahvasti kaikkien kyselyyn vastanneiden järjestöjen tavoitteena ja esimerkiksi sosiaalinen media sopii paremmin niille, joilla vaikuttaminen ei ole niin suuri osa toimintaa.

Tutkimuksessamme ei kuitenkaan löytynyt sellaisia vaikuttamiskanavia, joissa aktiivisemmin olisivat toimineet muuten passiiviset järjestöt. Tämä pätee myös sellaisten uusien internetpohjaisten vaikuttamisfoorumeiden kohdalla, joihin on asetettu paljon odotuksia. Aiemmin osassa kansainvälistä kirjallisuutta on korostettu, että perinteinen sisäpiirivaikuttaminen ja muut vaikuttamiskeinot pikemminkin tukevat toisiaan kuin ovat keskenään ristiriidassa (ks. Binderkrantz 2005). Tämä näyttää meidän tutkimuksemme mukaan pätevän myös uusien internet-pohjaisten vaikuttamiskeinojen kohdalla. Toisaalta, koska kaikista passiivisimmat ryhmät näyttivät käyttävän suhteellisesti eniten muun muassa sosiaalista mediaa, voisi tämä kertoa siitä, että sosiaalisella medialla voisi olla jonkinasteista potentiaalia voimaannuttaa heikompia. Julkisen sektorin luomilla konsultaatiofoorumeilla ei juuri tällaisia ominaisuuksia näytä olevan, joskaan ei myöskään erityisiä negatiivisessa mielessä silmiin pistäviä piirteitä.

Tulosten tulkinnassa on kuitenkin huomioitava, että olemme keskittyneet vain siihen, miten suomalaiset vaikuttajajärjestöt käyttävät eri 
vaikuttamiskeinoja. Sen sijaan, emme ole tutkineet sitä, miten ryhmät kokevat eri vaikuttamiskeinojen käytön, ja miten vaikuttavia ne todellisuudessa ovat. Todellisuudessa erilaisten vaikutuskeinojen tehokkuus vaihtelee merkittävästi. Yleisesti suoraa sisäpiirivaikuttamista pidetään tehokkaimpana vaikuttamisen tapana (Beyers 2004, 213). Jotkin keinot voivat puolestaan olla todelliselta vaikuttavuudeltaan sangen näennäisiä: mukaan pääsy poliittisiin prosesseihin ei ole sama asia kuin vaikutusvalta (Dur \& De Bievre 2007b), vaikka mukana olo on sen ehdottoman tärkeä edellytys. Lisää tutkimusta tarvittaisiinkin $\mathrm{mm}$. eri areenoilla toimimisen vaikuttavuudesta.

Olemme esittäneet, että havaittu vaikuttamisen kasautuminen tietyille järjestöille johtuisi maamme korporatistisista rakenteista. Pohdintaamme tukee se, että hieman samankaltaisia havaintoja tehtiin tanskalaisessa tutkimuksessa (Binderkrantz 2005). Tarvitaan kuitenkin lisää vertailukelpoista, ajantasaista, ja uudet vaikuttamiskeinot huomioivaa tutkimusta eri maista, jotta voitaisiin selvittää esimerkiksi, onko tämä vaikuttamisen kasaantuminen tyypillinen piirre kaikille korporatistisille maille vai kenties esimerkiksi erityisesti juuri Suomelle.

Esitimme myös näkemyksiä siitä, minkälaisia mekanismeja voisi olla havaitsemamme ilmiön taustalla. Näitä tekijöitä voisivat olla mm. tieto erilaisista vaikuttamiskeinoista tai asiantuntemus tehokkaasta vaikuttamisesta, joka rohkaisee muutenkin vahvoja vaikuttajia yrittämään. Tästä tutkimuksesta ei suoraan voida tehdä tällaista kausaalista johtopäätöstä ja tätä mahdollisuutta pitäisikin jatkossa selvittää tarkemmin.

Tämän tutkimuksen johtopäätöksenä toteamme kuitenkin ensinnäkin, että vaikuttajajärjestöjen aktiivisuudessa olevat erot näyttävät ainakin olevan maassamme sangen vaikea haaste erilaisten näkemysten tasaveroisen kuulemisen kannalta, joka ei näyttäisi ratkeavan helposti esimerkiksi vain rakentamalla uusia sähköisiä päätöksenteon vaikuttamisen areenoita, kuten viime aikoina on valtion taholta tehty. Uusia vaikuttamisareenoita näyttäisivät hyödyntävän eniten muutenkin aktiiviset toimijat. Toimijan halu vaikuttaa poliittisesti on vain yksi erilaisia aktiivisuuseroja selittävä tekijä - muut erot järjestöjen välillä kertovat järjestelmän jonkinasteisista vinoumista.
Toiseksi, tutkimuksemme perusteella yksi keskeinen vaikuttajajärjestöjen aktiivisuustason selittäjä ovat organisaatioiden eriävät taloudelliset resurssit. Uusien vaikuttamiskanavien rakentamista tärkeämpi keino edesauttaa erilaisten järjestöjen tasavertaisempaa vaikuttamista olisikin varmistaa erilaisille organisaatioille taloudelliset toimintaedellytykset, esimerkiksi painottamalla valtionavustusten jaossa heikompia järjestöjä. Tämä olisi tärkeää, sillä poliittiseen vaikuttamiseen osallistuvien työntekijöiden määrän yhteys aktiivisuuteen eri taktiikoissa korostaa jälleen kerran onnistuneen vaikuttamistyön ammattimaista luonnetta. Kiinnostava kysymys on, millaisia vaikutuksia tällä mahdollisella ammattimaistumisella on järjestödemokratialle. Jatkossa olisi kiinnostavaa tutkia, missä määrin järjestöissä työskentelevät vaikuttamisen ammattilaiset oligarkian rautaisen lain (Michels 1986) mukaisesti mahdollisesti etääntyvät järjestöjen rivijäsenistä.

Kolmanneksi, myönteisenä seikkana voimme mainita, että vaikuttajajärjestöjen intressien tyyppi ei juuri näytä selittävän ryhmien aktiivisuustasoa, ainakin kun muut tekijät kuten taloudelliset resurssit on kontrolloitu. Esimerkiksi elinkeinoelämän järjestöt eivät kuulu vaikkapa kansalaisjärjestöjä useammin kaikkein aktiivisimpiin ryhmiin. Tämä viittaa siihen, että kollektiivisen toiminnan ongelma, eli toisten ryhmien suuremmat haasteet vaikuttamisessa, ei välttämättä ole niin suuri rasite erilaisille järjestöille kuin kirjallisuuden perusteella voisi luulla. Tässä suhteessa havaintomme näyttäisivät poikkeavan intressiryhmätutkimuksen valtavirrasta, vaikkakin on otettava huomioon, että tulokset saattavat osaltaan johtua muuttujista, jotka eivät välttämättä tavoita kaikkia organisaatioiden välillä olevia eroja. Joka tapauksessa, mikäli erilaisten vaikuttajajärjestöjen vaikutusvallassa on havaittavissa eroja, tämä ei välttämättä tämän tutkimuksen perusteella johdu näiden ryhmien eri taktiikoiden käytön aktiivisuuden eroista, vaan mahdollisesti poliittisen järjestelmän eroista.

Kaiken kaikkiaan tutkimuksemme antaa enemmän tukea vaihtosuhdeteorialle (joka korostaa esimerkiksi resurssien merkitystä (esim. Godwin ym. 2013)) kuin pluralistiselle demokratiateorialle, vaikkakin esimerkiksi kollektiivisen toiminnan ongelma ei maassamme liene niin vahva ongelma kuin on oletettu. Näin on 
siksi, että järjestöjen välillä näyttää olevan paljon sellaisia eroja vaikuttamisen aktiivisuudessa, jota käyttämämme taustamuuttujat eivät tavoittaneet. Lisää tutkimusta tarvitaankin siitä, miksi tietyt järjestöt onnistuvat olemaan aktiivisia lähes jokaisella päätöksenteon areenalla, ja toiset eivät. Tämän voi olettaa olevan merkittävä ongelma monelle järjestölle, ainakin muissa korporatistisissa järjestelmissä, kuten Pohjoismaissa, ja mahdollisesti muissakin järjestelmissä.

Erilaisten järjestöjen vaikuttamisaktiivisuuden erot vaikuttavat epäilemättä myös poliittisten päätösten sisältöön. Potentiaaliset vinoumat myös poliittisten päätösten sisällössä voivat taas heikentää toisia toimijoita, jotka siten eivät pääse enää samalla tavalla mukaan vaikuttamistyöhön ja kehämäinen kierre on valmis (tähän voidaan viitata institutionalisoituneen edustuksen eliittikehällä, katso esim. Mattila ym. 2017). Viimeisenä johtopäätöksenä toteammekin, että vaikka vaikuttajajärjestöt ja muut intressiryhmät ovat oleellinen osa poliittisia prosesseja, on em. vinoumista johtuen tärkeää pitää huoli myös poliittis-hallinnollisen päätöksentekojärjestelmän itsenäisestä suorituskyvystä, esimerkiksi riittävistä resursseista puolueettoman tiedon tuotantoon. Toisaalta aina olisi tärkeä vahvistaa myös kansalaisten suoraa, intressiryhmistä riippumatonta, osallistumista.

\section{VIITTEET}

1 Ilmiö voi päteä laajasti muidenkin, muun muassa perinteisten julkisten vaikuttamiskeinojen kohdalla. Vahvan statuksensa vuoksi virallisiin elimiin mukaan päässeet toimijat esimerkiksi kiinnostavat mediaa uutislähteinä. Niillä on lisäksi sisäpiiritietoa, jota ne voivat käyttää mediaan vaikuttamisessa (vrt. Binderkrantz ym. 2015).

2 Kaikki mukaan? Avoin hallinto ja uudet osallistumismuodot -hanke (http://tietokayttoon.fi/hankkeet/hanke-esittely/-/asset_publisher/kaikki-mukaan-avoin-hallinto-ja-uudet-osallistumismuodot-kamu-).

3 Työryhmien osalta hyödynnettiin Anne Hollin keräämää aineistoa työryhmien jäsenistä.

4 interarena.dk

5 http://www.statisticssolutions.com/latent-class-analysis/

\section{TUTKIMUKSEN RAHOITUS}

Tätä tutkimusta ovat osittain rahoittaneet valtioneuvoston selvitys- ja tutkimustoiminta [KAMU-hanke], Suomen Akatemia [309934, Vesa] ja Koneen Säätiö [088880, Vesa].

\section{KIITOKSET}

Kiitämme artikkelikäsikirjoituksen arvijoitsijoita ja Vehkan väitöskirjaohjaajia hyvistä kommenteista.

\section{LÄHTEET}

Baumgartner, Frank \& Leech, Beth (1998). Basic interests: the importance of groups in politics and political science. Princeton: Princeton University Press. https://doi.org/10.1515/9781400822485

Baumgartner, Frank \& Leech, Beth (2001). Interest niches and policy bandwagons: patterns of interest group involvement in national politics. The Journal of Politics, 63(4), 1191-1213. https://doi.org/10.1111/0022-3816.00106

Beyers, Jan \& Braun, Caelesta (2014). Ties that count: explaining interest group access to policymakers. Journal of Public Policy, 34(1), 93-121. https://doi.org/10.1017/S0143814X13000263

Beyers, Jan (2004). Voice and access: political practices of European interest associations. European Union Politics 5(2), 211-240. https://doi.org/10.1177/1465116504042442

Binderkrantz, A. S., (2005). Interest group strategies: navigating between privileged access and strategies of pressure. Political Studies, 53, 694-715.

https://doi.org/10.1111/j.1467-9248.2005.00552.x

Binderkrantz, A., (2008). Different groups, different strategies: how interest groups pursue their political ambitions. Scandinavian Political Studies, 31(2), 173-200.

https://doi.org/10.1111/j.1467-

9477.2008.00201.x

Binderkrantz, Anne Skorkjær, Christiansen, Peter Munk \& Pedersen, Helene Helboe, (2015). Interest Group Access to the Bureaucracy, Parliament, and the Media. Governance: An International Journal of Policy, Administration, and Institutions, 28(1), 95-112. https://doi.org/10.1111/gove.12089

Binderkrantz, Anne Skorkjær; Chaqués Bonafont; Laura \& Halpin, Darren R., (2017). Diversity in the News? A Study of Interest Groups in the 
Media in the UK, Spain and Denmark. British Journal of Political Science, 47(2), 313-328. https://doi.org/10.1017/S0007123415000599

Bouwen, Pieter. 2002. Corporate lobbying in the European Union: the logic of access. Journal of European Public Policy 9:3, s. 365-390. https://doi.org/10.1080/13501760210138796

Chalmers, Adam William \& Shotton, Paul Alexander, (2015). Changing the face of advocacy? Explaining interest organizations' use of social media strategies. Political Communication, $00,1-18$.

https://doi.org/10.1080/10584609.2015.1043477

Della Porta, Donatella \& Diani, Mario, (1999). Social movements: an introduction. Oxford: Blackwell Publishers.

Dür, A. \& Mateo, G., (2013). Gaining access or going public? Interest group strategies in five European countries. European Journal of Political Research, 52, 660-686. https://doi.org/10.1111/1475-6765.12012

Dur, Andreas \& De Bievre, Dirk, (2007a). The question of interest group influence. Journal of Public Policy, 27(1), 1-12. https://doi.org/10.1017/S0143814X07000591

Dur, Andreas \& De Bievre, Dirk, (2007b). Inclusion without influence? NGOs in European trade policy. Journal of Public Policy, 27(1), 79-101. https://doi.org/10.1017/S0143814X0700061X

Dür, Andreas \& Mateo, Gemma, (2012). Who lobbies the European Union? National interest groups in a multilevel polity. Journal of European Public Policy, 19(7), 969-987. https://doi.org/10.1080/13501763.2012.672103

Dur, Andreas \& Mateo, Gemma, (2013). Gaining access or going public? Interest group strategies in five European countries. European Journal of Political Research 52(5), 660-686. https://doi.org/10.1111/1475-6765.12012

Eising, Rainer, (2007). Institutional context, organizational resources and strategic choices: explaining interest group access in the European Union. European Union Politics, 8, 329-362. https://doi.org/10.1177/1465116507079542

Godwin, Ken, Ainsworth, Scott \& Godwin, Erik, (2013). Lobbying and policymaking: the public pursuit of private interests. London: Sage Publications. https://doi.org/10.4135/9781483349336

Hagenaars, Jacques A. \& Halman Loek C., (1989). Searching for ideal types: the potentialities of latent class analysis. European Sociological Review, 5, 81-96. https://doi.org/10.1093/oxfordjournals.esr. a036509
Helander, Voitto, (1979). Interest representation in the Finnish committee system in the postwar era. Scandinavian Political Studies, 2(3), 221-237.

https://doi.org/10.1111/j.1467-9477.1979. tb00220.x

Hooghe, Marc, Ocer, Jennifer \& Marien, Sofie, (2016). A comparative analysis of 'good citizenship': A latent class analysis of adolescents' citizenship norms in 38 countries. International Political Science Review, 37 (1), 115-129. https://doi.org/10.1177/0192512114541562

Lijphart, Arendt, (2012). Patterns of Democracy: Government Forms and Performance in Thirtysix Countries. Second edition. New Haven and London: Yale University Press.

Linzer, Drew A. ja Lewis, Jeffrey B., (2011). poLCA: An R Package for Polytomous Variable Latent Class Analysis. Journal of Statistical Software, 42/10. https://doi.org/10.18637/jss.v042.i10

Matikainen, Janne, Talvitie-Lamberg, Karoliina \& Kunnas, Heikki, (2008). Virkamiesten asennoituminen verkko-osallistumista kohtaan. Hallinnon tutkimus, 27 (4), 3. artikkeli.

Mattila, Mikko, Rapeli, Lauri, Wass, Hanna \& Söderlund, Peter, (2017). Health and political engagement. London: Routledge. https://doi.org/10.4324/9781315561691

Michels, Robert (1986). Puoluelaitos nykyajan demokratiassa. Porvoo: Werner Söderström.

Nelimarkka, M., (2011). Viranomaiset ja sähköinen kansalaisosallistuminen: asiantuntijahaastatteluiden perusteella luotu aktantiaalinen malli. Hallinnon tutkimus, 30(2), 158-169.

Oikeusministeriö, (2010). Yleishyödylliset palvelut, valtionavustukset ja kansalaisjärjestöt. Oikeusministeriön julkaisu (Selvityksiä ja ohjeita 41/ 2010). Edita Prima Oy, Helsinki.

Oikeusministeriö, (2017). Demokratiapoliittinen toimintaohjelma. Oikeusministeriön julkaisu 7/2017. Lönnberg Print \& Promo, Helsinki.

Olson, M., (1965). The logic of collective action. Cambridge: Harvard University Press.

Oser, Jennifer, Hooghe, Marc \& Marien, Sofie, (2013). Is online participation distinct from offline participation? A latent class analysis of participation types and their stratification. Political Research Quarterly, 66(1), 91-101. https://doi.org/10.1177/1065912912436695

Rainio-Niemi, Johanna, (2010). State Committees in Finland in Historical Comparative Perspective. Teoksessa Alapuro, R. \& Stenius, H., (toim.), Nordic Associations in a European Perspective. Baden-Baden: Nomos Verlagsgesellschaft. https://doi.org/10.5771/9783845225944-241 
Saari, Milja, (2012). Rinta rinnan Suomea kehittämässä? Teoksessa Helander, M. \& Nylund, M. (toim.), Palkka työstä: ay-liike ja edunvalvonnan uudet muodot, s. 95-126. Helsinki: Into Publishing.

Scaramuzzino, G., \& Scaramuzzino, R., (2017). The weapon of a new generation?-Swedish Civil Society Organizations' use of social media to influence politics. Journal of Information Technology \& Politics, 14(1), 46-61. https://doi.org/10.1080/19331681.2016.1276501

Schattschneider, E. E. (1960). The semi-sovereign people. A Realist's View of Democracy in America. Reprint, Boston: Wadsworth, 1975.

Temmes, Markku, (2001). Määräaikaisen valmistelun kehittäminen. Helsinki: Valtiovarainministeriö.

Van der Graaf, A., Otjes, S. \& Rasmussen, A., (2016). Weapon of the weak? The social media landscape of interest groups. European Journal of Communication, 31(2), 120-135.

https://doi.org/10.1177/0267323115612210

Vesa, J., Kantola, A. \& Binderkrantz, A.S., (2018).
A stronghold of routine corporatism? The involvement of interest groups in policy making in Finland. Scandinavian Political Studies, 41(4): 239-262.

https://doi.org/10.1111/1467-9477.12128

Vesa, Juho \& Kantola, Anu, (2016). Kuka pääsee mukaan? Miten järjestöjen ääni kuuluu lakien valmistelussa. Valtioneuvoston selvitys- ja tutkimustoiminta. Haettu sivulta http://tietokayttoon.fi/documents/10616/2009122/59_ Kuka+pääsee+mukaan_Miten+järjestöjen+ ääni+kuuluu+lakien+valmistelussa/0eb41bfb-5c4e-439a-b898-e313d9f2570c?version=1.1, 18.10.2018.

Wright, Scott, (2016). 'Success' and online political participation: the case of Downing Street E-petitions. Information, Communication \& Society, 19(6), 843-857. https://doi.org/10.1080/1369118X.2015.1080285

Öberg, Perola, (2002). Does administrative corporatism promote trust and deliberation? Governance, 15(4), 456-475. https://doi.org/10.1111/0952-1895.00197 